UDK 631.331:061.4

\title{
PNEUMONITIS FRACTIONATION OF GRAIN MATERIALS IN AIR STREAMS OF VARIABLE STRUCTURE
}

\author{
S. P. Stepanenko', B. I. Kotov ${ }^{2}$ \\ ${ }^{1}$ National Scientific Center "Institute of Mechanization and Electrification of Agriculture". Ukraine. \\ ${ }^{2}$ Podolsky State Agricultural and Technical University. Ukraine.
}

Speciality of article: 133 - industry engineering.

Corresponding authors: stepanenko_s@ukr.net.

Article history: Received - October 2019, Accepted-January 2020.

Bible. 13, fig 4, tabl. 0.

Abstract. The paper presents the results of a theoretical study of the interaction of particles of grain material components with countercurrent flow of material into the air flow and variable flow velocity curves along the coordinate axes. It is established that the use of variable speed increases the magnitude of the splitting of the trajectories of motion and the efficiency of separation.

Analyzing the results of mathematical modeling of the ballistics of the particles of the components of the grain material can be determined that the increase in the magnitude of splitting (branching) trajectories of the particle motion when using variable air velocity at the coordinates. The increase in the magnitude of the splitting of the trajectories unambiguously characterizes the increase of the efficiency of separation of components of the grain material into fractions according to the aerodynamic properties, which are known to tightly correlate with the qualitative indices of the grain material.

The results of research of process of inertial fractionation indicate real opportunities to improve the efficiency of separating the material into fractions according to aerodynamic properties. The effect of the velocity plot of air in the air channel can be used to control the processes of separating the material into fractions.

Key words: grain material, aerodynamic properties, air flow, trajectory of particle separation into fractions.

\section{Introduction}

Addressing division multi-grain material into separate fractions particular purpose has significant importance in post-harvest handling and processing of grain $[1,3,5,11]$. The need to improve the efficiency of grain separation machines due to increased requirements for grain quality and intensity resource energetic balance grain production farms.

Analysis of existing methods for purification and separation of grain material shows that the process of improving individual components and the working of the machines, optimizing operational parameters of energy efficiency of processes and machines in specific rates virtually unchanged. This situation is due to the fact that the improvement grain separation machine does not change the basic features of their operation.

The basis of grain cleaning and separating equipment currently account latticework and air-sieve machine. The presence of the fast, oscillating or vibrating nodes causes more dynamic load on structural elements of the machine, which affects performance increases relative weight machines working sieves tenfold themselves sieves require complex mechanisms for their drive and balance the inertial forces.

A promising direction is to create sieveless air separators $[8,9,10]$.

Air (pnevmo inertia) separation compared to other methods of separation of the multi grain material is voluminous in nature and in the absence sieve material can handle any moisture and debris.

\section{Formulation of problem}

However, studies conducted [1] there is no consensus about the efficiency of operation at heavy loads.

We consider the fundamental capabilities grain fractionation efficiency air flows of materials by analyzing mathematical models of moving grain component material in the air flow.

The most common vertical pneumosupply channels provide high quality separation (separation into fractions) with minor material feed supply by increasing the quality of their work is reduced due to an increase in collisions between particles. Horizontal air streams (channels) have the advantage that the direction of gravity and aerodynamic forces are not the same, and the number of collisions is negligible.

Pneumo-inertion separation is done by "stuffing" the grain mass in a moving layer of air where the resulting difference in air resistance and components introduced with a fairly large (3-6 m/ s) speeds are split trajectories.

The peculiarity of presenting the material in a counter flow of air is possible to increase the speed of 
interaction of air flow without increasing the speed of the latter and increasing the feed rate of the material.

To identify the basic laws of fractionation mechanism pnevmo inertia the basic mathematical model of particles with different aerodynamic properties (speed greetings, drag coefficient, or distribution) in the air flow depending on the speed and angle of the input airflow.

Consider moving components (trajectory) grain material by changing the airflow in the direction of its movement in the direction of gravity. It is shown that when air speed distributioncoordinate value increases the branching paths, and this is achieved by improving the efficiency of fractionation.

In the mathematical model the influence of fluctuations in airflow character moving components of the grain material.

Identified laws of motion of particles in a single approach that can be distributed to a plurality of particles each component grain material.

\section{Analysis of recent research results}

The problem of increasing the productivity and quality of air separation of grain cleaning machines working on technologies fractionation by improving the working bodies and their operation modes adequately covered in the monograph [8] and the works of individual authors [2-4].

Proven efficient processes pneumonitis fractionation of grain materials [3-5].

Among a wide class of air (aerodynamic) separators occupy a significant place machines that use horizontal air flow [5, 6] with a bottom material discharge, but also optimization of the operating parameters: set the angle of the feed rate of material into the air flow and speed the flow of other ways to intensify the split in the literary sources not found.

However, it is known [6,7], changes in the structure (the velocity plot of air) flows, it is possible to achieve a significant improvement in the separation of grain materials into fractions according to technological purpose.

\section{Purpose of research}

The aim of the study was to determine the effectiveness and feasibility of the application of the principle changes in the flow velocity of air at the introduction of material into the working chamber (pneumococal).

\section{Results of research}

Consider the motion of the components of the grain material, which are different aerodynamic properties. A comprehensive measure of the aerodynamic properties, which can be adopted to quantify the ratio $k_{V}$ [8]:

$$
k_{V}=\frac{C(R e) S_{M} \rho}{2 m}=\frac{g}{V_{\mathrm{B}}^{2}}
$$

where: $C(R e) R e$ - the drag coefficient as function of Reynolds number (),

$S_{M}$ - the cross-sectional area, $\mathrm{m}^{2}$,

$\rho$ - the density of the air, $\mathrm{m}^{3}$,

$m$ - mass of the particle, $\mathrm{kg}$,

$g-$ acceleration of free fall, $\mathrm{m} / \mathrm{sec}^{2}$,

$V_{\mathrm{B}}-$ speed, $\mathrm{m} / \mathrm{sec}$.

The aerodynamic force of resistance to air flow is proportional to the square of the relative velocity $\mathrm{U} R$ :

$$
R=\frac{C(R e) S_{M} \rho U^{2}}{2} .
$$

The particle motion occurs in the plane rectangular Cartesian coordinate system OXY in the channel of variable cross section. The air flow is directed horizontally, the supply of material (introduction of particles of the components of the grain material) in the channel is at an angle (to the axis OX) with an initial speed relative to the schema in Fig. 1. $\alpha_{0} V_{0}$

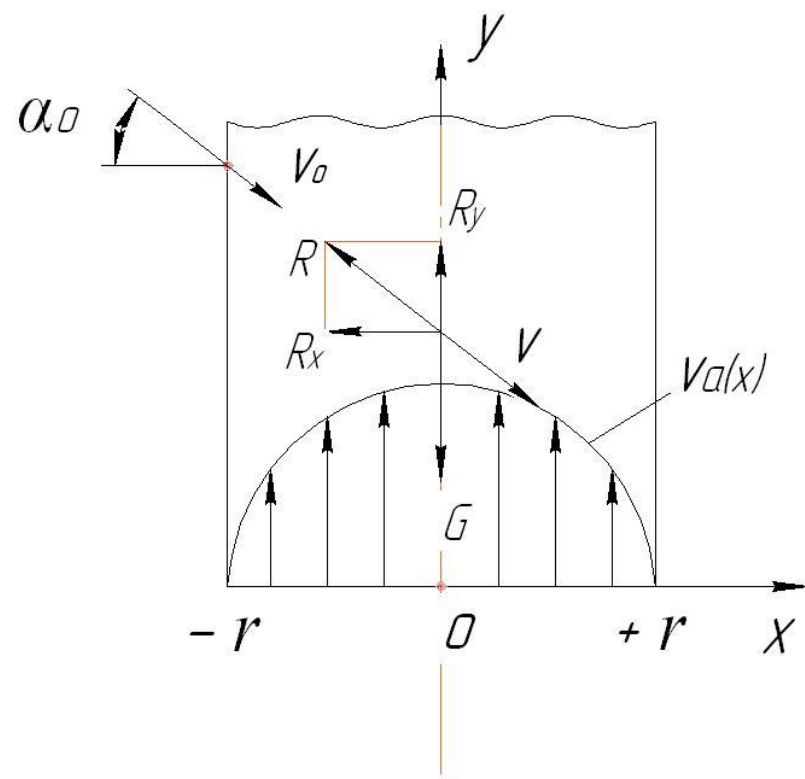

Fig. 1. The scheme of movement of the particles in the air duct.

The insertion of particles of the components of the grain material in the counter air flow and the speed of the initial motion of the particles and determine their trajectory in the working space of the separator chamber.

After the introduction of the components in the horizontal flow, they begin to interact with the air flow moving in the horizontal direction against the axis OX.

To describe the movement of single particles in the air stream defined generally accepted simplifying assumptions idealizing the research process:

- Particle move "in isolation" without interacting with the walls of the chamber (channel) and other particles

- Particle oriented in the air in a stationary position its rotation is not considered,

- The air flow in the cross section perpendicular to the direction of the uniform,

- The air velocity in the directions OX and OU set a variable with the coordinate method of implementation of the velocity distribution is not considered. 
For the adopted scheme of interaction of a particle with a mass airflow variable speed and taking into account the accepted assumptions the resulting system of differential equations that describes the movement of material in a moving air environment $m V_{\mathrm{x}} V_{\mathrm{y}}$ :

$$
\frac{d^{2} y}{d \tau^{2}}=g-k_{V}\left(\frac{d y}{d \tau}\right) \sqrt{\left(\frac{d y(\tau)}{d \tau}\right)^{2}+\left(\frac{d x(\tau)}{d \tau}+V_{\mathrm{x}, \mathrm{y}}\right)^{2}},
$$

$$
\frac{d^{2} x}{d \tau^{2}}=-k_{V}\left(V_{\mathrm{x}, \mathrm{y}}+\frac{d \mathrm{x}}{d \tau}\right) \sqrt{\left(\frac{d y(\tau)}{d \tau}\right)^{2}+\left(V_{\mathrm{x}, \mathrm{y}}+\frac{d \mathrm{x}}{d \tau}\right)^{2}}
$$

The initial conditions are determined by the ratios $\tau=0, x=\mathrm{y}=0$,

$$
y_{0}=y_{0}, \mathrm{x}_{0}(0)=\mathrm{x}_{0}, \dot{\mathrm{x}}_{0}=\frac{d \mathrm{x}}{d \tau}=V_{0} \cos \alpha_{0}, \dot{\mathrm{y}}_{0}=\frac{d \mathrm{y}}{d \tau}
$$

$$
=V_{0} \sin \alpha_{0} \text {. }
$$

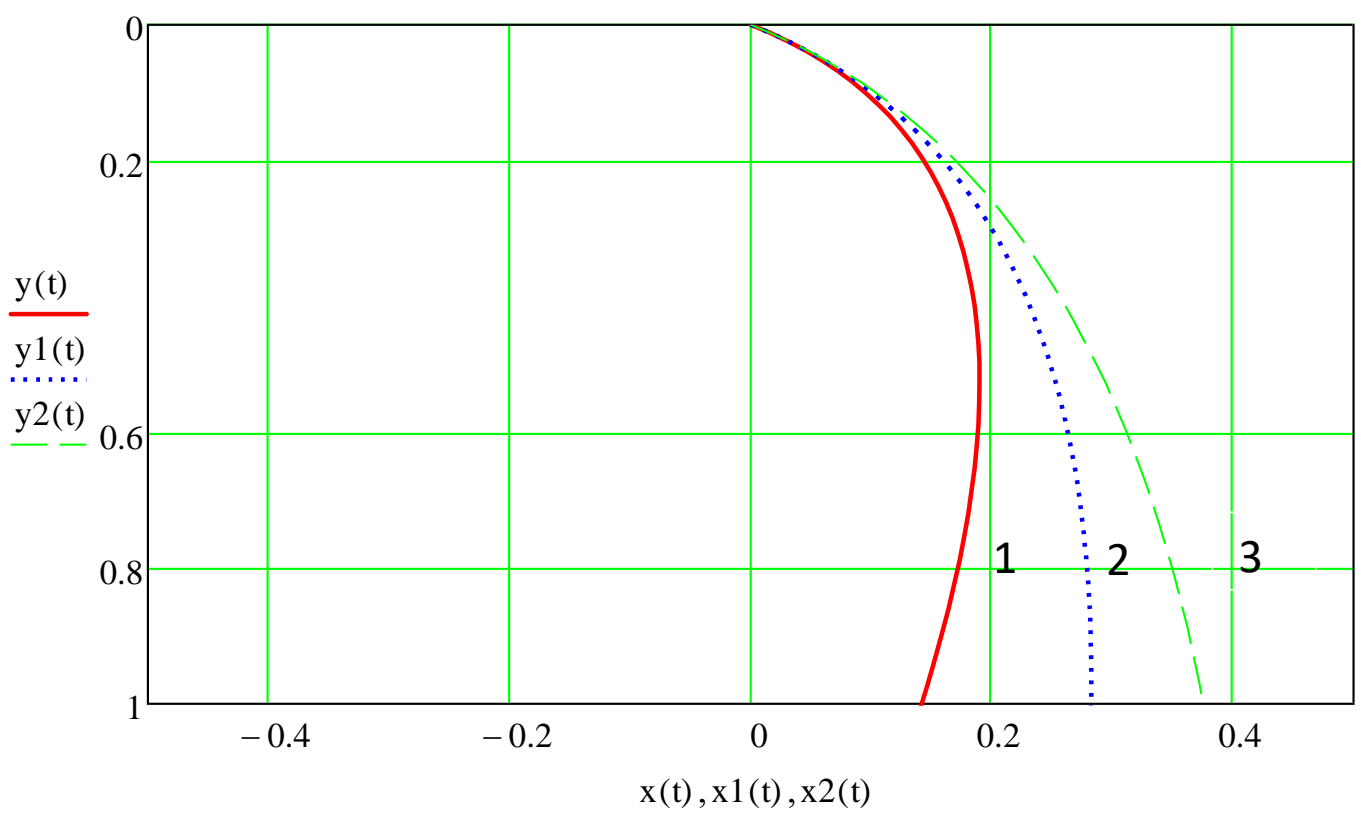

Fig. 2. The trajectory of the components of the grain material at a constant in the directions of the coordinate velocity of the air. $1-2-3-V_{\text {віт }}=7,3 \frac{\mathrm{m}}{\mathrm{sec}}, V_{\text {віт }}=9 \frac{\mathrm{m}}{\mathrm{sec}}, V_{\text {віт }}=11 \frac{\mathrm{m}}{\mathrm{sec}}$.

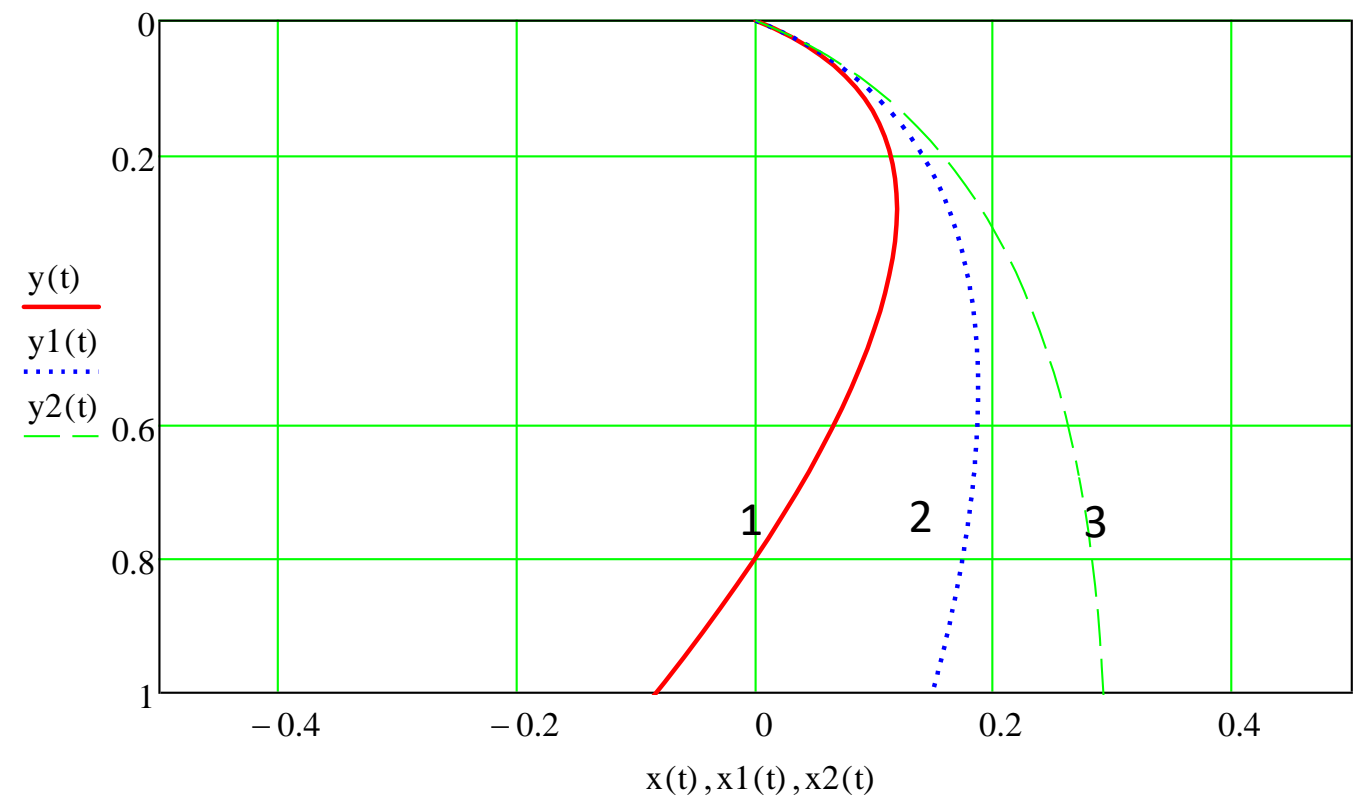

Fig. 3. The trajectory of particle motion with increasing speed of the air flow in the direction of its motion according to a linear law. $1-2-3-V_{\text {віт }}=7,3 \frac{m}{s e c}, V_{\text {віт }}=9 \frac{m}{s e c}, V_{\text {віт }}=11 \frac{m}{s e c}$.

The results are presented in the form of trajectories of particles with different coefficient (different velocity components of the grain material) $k_{V}$.

In Fig. 2 given the trajectory of the components at a constant in the directions of the coordinate velocity of the air. In Fig. 3 shows the trajectory of particle motion with increasing speed of the air flow in the direction of its motion according to a linear law $V=a-b x$.

In Fig. 4 shows the trajectories of the particles while increasing air velocity in the direction perpendicular to the movement of air according to a linear law $V=a-b y$. 


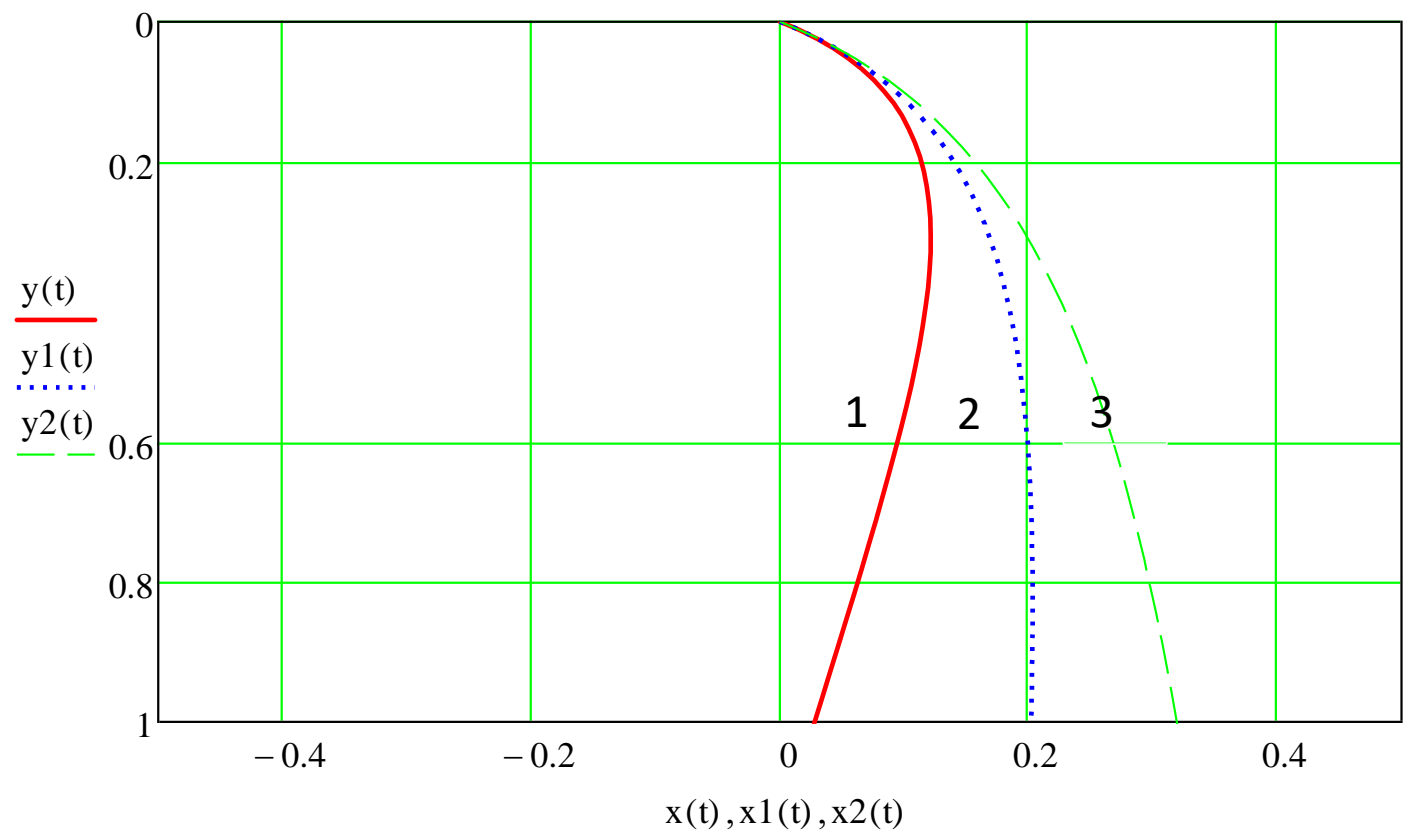

Fig. 4. The trajectory of the particles while increasing air velocity in the direction perpendicular to the movement of air according to a linear law. $1-2-3-V_{\text {віт }}=7,3 \frac{\mathrm{m}}{\mathrm{sec}}, V_{\text {віт }}=9 \frac{\mathrm{m}}{\mathrm{sec}}, V_{\text {віт }}=11 \frac{\mathrm{m}}{\mathrm{sec}}$.

Analyzing the results of mathematical modeling of the ballistics of the particles of the components of the grain material can be determined that the increase in the magnitude of splitting (branching) trajectories of the particle motion when using variable air velocity at the coordinates. The increase in the magnitude of the splitting of the trajectories unambiguously characterizes the increase of the efficiency of separation of components of the grain material into fractions according to the aerodynamic properties, which are known to tightly correlate with the qualitative indices of the grain material.

\section{Conclusions}

1. The results of research of process of inertial fractionation indicate real opportunities to improve the efficiency of separating the material into fractions according to aerodynamic properties.

2. The effect of the velocity plot of air in the air channel can be used to control the processes of separating the material into fractions.

\section{References}

1. Aniskevich, L. V., Starodubtsev, V. M. (2015), Estimation of spatial heterogeneity of the soil cover of forest-Steppe plains. Scientific Bulletin of National University of life and environmental Sciences of Ukraine. Series: electronics and energetics, agriculture. Vol. 226. 115-123.

2. Bublyas, M. V. (2011). Geological action of pore solutions in the conditions of diagenesis of sedimentary rocks. Collection of scientific works of the Institute of geological Sciences of the NAS of Ukraine. Vol. 4. 39-46.

3. Gedroits, K. K. (1955). Selected works. Moscow. Selkhozgiz. 600.
4. Godelman, Y. M. (1981). Heterogeneity of the soil cover and land use. Moscow. Science. 200.

5. Medvedev, V. V. (2007). Heterogeneity of soils and precision agriculture. Part 1. Introduction to the problem. Kharkov. UAAS, 262.

6. Starodubtsev, V. M., Yatsenko, S. V., Pavlyuk, S. D., Ilyenko, $V$. V. (2009). Influence of water regime of Forest scrosati to the heterogeneity of the soil cover and its use. II all-Ukrainian Congress of ecologists with international participation. Ecology-2009. 23-26 September 2009. Vinnitsa. 176-179.

7. Starodubtsev, V. M., Rozstalnyy, Ye. V., Yatsenko, S. V., Bordas, A. A. (2010). Water regime scrosati as a factor of heterogeneity of the soil cover of the right-Bank forest-Steppe. Scientific Bulletin of National University of life and environmental Sciences of Ukraine. Series: Agroengineering. Vol. 149. 108-112.

8. Starodubtsev, V. M., Bogdanets, V. A. (2015). New perspective on mapping and assessment of the heterogeneity of the soil cover of forest-Steppe plains. Collection of scientific works SWorld. Issue No 1(38). 89-94.

9. Starodubtsev, V. M., Aniskevich, L. V. Urban, B. V. (2015). To assess the spatial heterogeneity of the soil cover of forest-Steppe plains. Scientific works SWorld. T. 11. Vol. 3(40). Agriculture. 4-11.

10. Starodubtsev, V. M., Aniskevich, L. V., Vlasenko, C. I. (2016). Features of the soil cover and the water regime of soils on the plains of the right Bank forest-Steppe. XV international correspondence conference "Development of science in the XXI century" (15.07.2016 years). 1 part. Kharkov. Nits "Knowledge". 152-156.

11. Starodubtsev, V. M., Komarchuk, D. S., Bogdanets, V. A., Vlasenko, C. I. (2016). New tools for the study of spatial heterogeneity of the soil cover. The Right-Bank Forest-Steppe. XV international correspondence conference "Development of science in 
the XXI century" (15.07.2016 years). 1 part. Kharkov. Nits "Knowledge". 82-86.

12. Starodubtsev, V. M., Vlasenko, S. I., Basarab, G. M., Komarchuk, D. S. (2018). Spatial heterogeneity of winter wheat yields in the fields with mclosetime. Scientific reports of National University of life and environmental Sciences of Ukraine. №3 (73). 8.

13. Starodubtsev, V. M., Vlasenko, S. I., Basarab, G. M., Komarchuk, D. S. (2018). Spatial heterogeneity of the water regime and flow of a typical Chernozem of the right-Bank Ukraine. Steppes of Northern Evrasiataxi VIII international симпозиума_1.pdf. Orenburg. 946-949. www.orensteppe.org.

\section{Список літератури}

1.Аніскевич Л. В., Стародубиев В. М. Оцінка просторової неоднорідності грунтового покриву рівнинного Лісостепу. Науковий вісник Національного університету біоресурсів i природокористування України. Серія: техніка та енергетика АПК. 2015. Вип. 226. С. 115-123.

2.Бублясь М. В. Геологічна дія порових розчинів в умовах діагенезу осадових порід. Збірник наукових праць Інтитуту геологічних наук НАН України. 2011. Вип. 4. С. 39-46.

3.Гедройц К. К. Избранные сочинения. Москва. Сельхозгиз. $1955.600 \mathrm{c}$.

4.Годельман Я. М. Неоднородность почвенного покрова и использование земель. Москва. Наука. 1981. $200 \mathrm{c}$.

5.Медведев B. В. Неоднородность почв и точное земледелие. Часть 1. Введение в проблему. Харьков. УАAН, 2007. $262 \mathrm{c}$.

6.Стародубиев В. М., Яиенко С. В., Павлюк С. Д., Іллєнко $B . B$. Вплив водного режиму мікрозападин Лісостепу на неоднорідність грунтового покриву та його використання. II Всеукраїнський з'їзд екологів 3 міжнародною участю. Ecology-2009. 23-26 вересня 2009 року. Вінниця. 2009. С. 176-179.

7.Стародубиев В. М., Розстальний В. С., Яцеенко $C . \quad B .$, Бордусь $O . \quad O$. Водний режим мікрозападин як фактор неоднорідності грунтового покриву правобережного Лісостепу. Науковий вісник Національного університету біоресурсів і природокористування України. Серія: агроінженерія. 2010. Вип. 149. С. 108-112.

8.Стародубиев В. М., Богданецьь В. А. Новий погляд на картування й оцінку неоднорідності грунтового покриву рівнинного Лісостепу. Сборник научных трудов SWorld. 2015. Выпуск №1(38). С. 8994.

9. Стародубиев В. М., Анискевич Л. В., Урбан Б. В. К оценке пространственной неоднородности почвенного покрова равнинной Лесостепи. Научные труды SWorld. Т. 11. Вып. 3(40). 2015. Сельское хозяйство. С. 4-11.

10. Стародубиев В. М., Аніскевич Л. В., Власенко I. C. Особливості грунтового покриву i водного режиму грунтів на рівнинах Правобережного Лісостепу. XV Международная заочная конференция
«Развитие науки в XXI веке» (15.07.2016 года). 1 часть. Харьков. НИЦ «Знание». 2016. С. 152-156.

11. Стародубиев В. М., Комарчук Д. С., Богданець В. А., Власенко I. C. Нові технічні засоби для дослідження просторової неоднорідності грунтового покриву. Правобережного Лісостепу. XV Международная заочная конференция «Развитие науки в XXI веке» (15.07.2016 года). 1 часть. Харьков. НИЦ «Знание». 2016. С. 82-86.

12. Стародубиев В. М., Власенко I. С., Басараб Р. М., Комарчук Д. С. Просторова неоднорідність врожаїв озимої пшениці на полях з мікрозападинами. Наукові доповіді Національного університету біоресурсів і природокористування України. 2018. №3 (73). 8 с.

13. Стародубиев В. М., Власенко И. С., Басараб Р. М., Комарчук Д. С. Пространственная неоднородность водного режима и продуктивности типичных черноземов Правобережной Украины. Степи Северной Евразии_материалы VIII международного симпозиума_1.pdf. Оренбург. 2018. С. 946-949. www.orensteppe.org.

\section{ПНЕВМОІНЕРЦІЙНЕ ФРАКЦІОНУВАННЯ ЗЕРНОВИХ МАТЕРІАЛІВ В ПОВІТРЯНИХ ПОТОКАХ ЗМІННОЇ СТРУКТУРИ С. П. Степаненко, Б. І. Котов}

Анотація. У роботі наведені результати теоретичного дослідження взаємодії часток компонентів зернового матеріалу при протипотокової подачі матеріалу в повітряний потік і при змінних епюрах швидкості потоку вздовж осей координат. Встановлено, що використання змінної швидкості збільшує величину розщеплення траєкторій руху i ефективність розділення.

Аналізуючи отримані результати математичного моделювання балістики частинок компонентів зернового матеріалу можна визначити, що збільшення величини розщеплення (розгалуження) траєкторій руху частинок при використанні змінної швидкості повітряного потоку за координатами. Збільшення величини розщеплення траєкторій однозначно характеризує збільшення ефективності поділу компонентів зернового матеріалу на фракції по аеродинамічним властивостям, які як відомо щільно корелюють 3 якісними показниками зернового матеріалу.

Отримані результати досліджень процесу інерційного фракціонування свідчать про реальну можливість підвищення ефективності поділу матеріалу на фракції по аеродинамічних властивостях. Ефект епюри швидкості повітря в повітряному каналі може бути використано для управління процесами поділу матеріалу на фракції.

Ключові слова: зерновий матеріал, аеродинамічні властивості, повітряний потік, траєкторія поділу частинок на фракції. 


\section{ПНЕВМОИНЕРЦИОННОЕ ФРАКЦИОНИРОВАНИЕ ЗЕРНОВЫХ МАТЕРИАЛОВ В ВОЗДУШНЫХ \\ ПОТОКАХ ПЕРЕМЕННОЙ СТРУКТУРЫ \\ С. П. Степаненко, Б. И. Котов}

Аннотация. В работе приведены результаты теоретического исследования взаимодействия частиц компонентов зернового материала при противоточной подаче материала в воздушный поток и при переменных эпюрах скорости потока вдоль осей координат. Установлено, что использование переменной скорости увеличивает величину расщепления траекторий движения и эффективность разделения.

Анализируя полученные результаты математического моделирования баллистики частиц компонентов зернового материала можно определить, что увеличение величины расщепления (ветвления) траекторий движения частиц при использовании переменной скорости воздушного потока по координатам. Увеличение величины расщепления траекторий однозначно характеризует увеличение эффективности разделения компонентов зернового материала на фракции по аэродинамическим свойствам, которые как известно плотно коррелируют с качественными показателями зернового материала.

Полученные результаты исследований процесса инерционного фракционирования свидетельствуют о реальной возможности повышения эффективности разделения материала на фракции по аэродинамическим свойствам. Эффект эпюры скорости воздуха в воздушном канале может быть использовано для управления процессами разделения материала на фракции.

Ключевые слова: зерновой материал, аэродинамические свойства, воздушный поток, траектория разделения частиц на фракции.

S. P. Stepanenko ORCID 0000-0002-9307-2796.

B. I. Kotov ORCID 0000-0003-2369-7288. 